\title{
Measurement of Tannic Substances in Forest Species
}

\author{
Jordânia Xavier de Medeiros ${ }^{1}$ (D), Leandro Calegari² ${ }^{2}$ Girlânio Silva ${ }^{3}$, \\ Elisabeth Oliveira ${ }^{2}$, Alexandre Pimenta ${ }^{4}$ \\ ${ }^{1}$ Universidade Federal Rural de Pernambuco - UFRPE, Recife/PE, Brasil \\ ${ }^{2}$ Universidade Federal de Campina Grande - UFCG, Patos/PB, Brasil \\ ${ }^{3}$ Universidade Estadual Paulista "Júlio de Mesquita Filho" - UNESP, Botucatu/SP, Brasil \\ ${ }^{4}$ Universidade Federal do Rio Grande do Norte - UFRN, Macaíba/RN, Brasil
}

\begin{abstract}
This study aimed to quantify the tannic content of the barks and fruit of angico-vermelho, jurema-preta and acacia-negra using skin powder as detanizador agent. Materials from these species were ground and classified, with $12.5 \mathrm{~g}$ of air dried particles subjected to extraction using a steam jacket type extractor to obtain $1000 \mathrm{ml}$ of solution, using a completely randomized analytic design. The solution was evaluated using four treatments: angico bark; jurema bark; acacia bark and angico fruit. Three replicates per treatment were realized and subrepetitions were analyzed in triplicate. The results were interpreted by comparison of means with Tukey test at $5 \%$ significance. Best results in terms of total solids content, were observed in acacia bark $(67.2 \%)$, differing statistically for angico bark (63.5\%). The soluble solids content, in turn, was superior to angico bark (60.3\%), differing statistically from acacia bark (49.8\%). No statistically significant differences for tannin content were observed between acacia and angico barks, which presented values of 28.4 and $26.8 \%$, respectively.
\end{abstract}

Keywords: skin powder, extractive, vegetable tannins. 


\section{INTRODUCTION}

Tannic agents may be understood as natural, synthetic or mineral substances capable of transforming skin into leather, which occurs due to chemical bonds between the collagen of the skin and polyphenols (Panshin et al, 1962; Haslam, 1966). The hydrolysable tannins are composed by glucose polyesters and the acid formed; their hydrolysis is classified into gallic tannins or ellagi tannins (Pizzi, 1993; Ricci et al., 2015). The condensed tannins, in turn, known as flavanols, are formed by catechin monomers (Haslam, 1966; Wenzl, 1970; Pizzi, 1993).

A lack of proper management, coupled with uncontrolled exploitation of angico vermelho and jurema preta, especially due to the lack of options in terms of species for tannin production, which would make it possible to constitute mixtures for skin tanning over the short term, has led to a depletion of these forest species, as well as affecting the production chain and the livelihood of families that depend on them (Diniz et al., 2003). In this context, jurema (Mimosa tenuiflora (Willd.) Poir.), a fast growing species common in disturbed areas of Caatinga and widely used for the production of firewood, charcoal and wood for cooking, was highlighted in research where its tannin content appears sufficient to warrant further investigation to more precisely determine its potential for use in the tanning production chain (Paes et al., 2006a).

Due to the complexity of tannins, which are substances formed by different chemical structures, there is no single methodology for their quantification. Given this, various methods have been adopted when considering this substance. The method which uses skin powder is one of the methods recommended to analyze tannins for tanning (Yazaki et al., 1993; Falcão \& Araújo, 2013; Malacarne et al., 2017).

Few studies have been realized to investigate the occurrence of species in the Caatinga, particularly studies seeking to extract and quantify tannins in species, which present potential for commercial exploitation for this purpose (Paes et al., 2006a; Paes et al., 2006b; Lima, 2011).

The present study aimed to quantify the tannic substances in the bark and fruits of angico vermelho, jurema preta, and acacia negra, using skin powder as detanizador agent.

\section{MATERIAL AND METHODS}

\subsection{Collection and preparation of material}

Ten adult angico vermelho and ten jurema preta were selected in the municipality of Malta, Paraíba. The trees were randomly selected and spread evenly throughout the area, aiming to take into account the variability of the area.

The removal of the bark and fruit was performed in situ without killing the tree, using hand tools including knives and a wooden mallet. The samples were maintained in a well lit, ventilated environment, to promote natural drying. Subsequently, they were stored in plastic bags and transported to the Laboratory of Technology Forest Products, at the Federal University of Campina Grande (UFCG). In order to represent the genetic variability between the sampled plants, bark samples were taken from three positions on the trunk (base, middle and top), in the branches and from the thinner twigs, in order to represent the whole tree.

Acacia negra bark was also employed, which was obtained in the form of large fragments. This bark came from five individual trees of a forest stand, located in the city of Pelotas, Rio Grande do Sul, having been obtained a year prior to the collection of the other materials.

The materials were fragmented individually by species and type. Firstly, they were submitted to a hammer mill, then to grinding in a Wiley mill, thereby producing a material with a smaller particle size. To avoid overheating the mill, milling was performed slowly with periodic stops (Paes et al., 2006a)

The bark particles were classified in a vibrating screen such that the portion that passed through the 40 mesh $(0.425 \mathrm{~mm})$ but was retained on 60 mesh screen $(0.25 \mathrm{~mm})$ was used. The particles were stored in numbered and sealed bottles, protected from light and humidity.

\subsection{Generation of analytical solution}

$12.5 \mathrm{~g}$ of air dried particles were extracted, using a steam jacket type metal extractor (ASTM, 2004a).

The particles were pre-moistened with distilled water for $24 \mathrm{~h}$. While still damp, they were placed in the extraction chamber, which contained a cotton wool 
layer at the bottom. The extraction to obtain $1000 \mathrm{ml}$ of analytical solution followed.

\subsection{Determination of moisture particles}

Simultaneous with the removal of the sample to generate the analytical solution (primary sample), a secondary sample (air dried) was obtained, which was placed in an oven $\left(100{ }^{\circ} \mathrm{C}\right)$ to obtain its anhydrous mass, in order to calculate moisture content on wet based (Equation 1) by D 6403-99 (ASTM, 2004c).

$$
M C \%=((D m a-B u t) / A d m) \cdot 100
$$

In which:

$\mathrm{MC} \%=$ moisture content of the secondary sample (\%); Dma $=$ air dried mass of secondary sample $(3 \mathrm{~g})$; Adm = Anhydrous dry mass of the secondary sample (g).

\subsection{Determination of the anhydrous mass of the particles submmited to extraction}

Knowing the moisture content (secondary sample) and air dried mass of the portion transferred to the extraction chamber (primary sample), the anhydrous mass of the sample that was submitted to extraction was calculated (Equation 2).

$$
\text { Mae }=\text { Mue. }[1-(M C \% / 100)]
$$

In which:

Mae $=$ anhydrous mass dry sample used in the extraction, in g;

Mue $=$ air dried mass of the sample used in the extraction (12.5g) in $\mathrm{g}$.

$\mathrm{MC} \%=$ moisture content of secondary sample (Equation 1), in \%.

\subsection{Determination of total solids}

Determination of Total Solids (TS) was performed according to the standards D 6402-99 (ASTM, 2004b), IS 5466, NBR 11125 (ABNT, 2002) and ISO 14088 (ISO, 2009). After stirring the crude analytical solution, a $50 \mathrm{ml}$ aliquot was pipetted, which was dried in an oven $\left(100^{\circ} \mathrm{C}\right)$ to obtain its anhydrous mass, calculating the TS, according to Equation 3.

$T S \%=($ Mar $/$ Mae $) \cdot 100$
In which:

TS $=\%$ total solids;

Sea $=$ dry mass $(\mathrm{g})$ of the residue extrapolated to the total volume of the solution (1L);

Mae $=$ dry mass $(\mathrm{g})$ of the sample used in the extraction (Equation 2).

\subsection{Determination of soluble solids}

The determination of soluble solids was performed according to the standards D 6402-99 (ASTM, 2004b), IS 5466, NBR 14362 (ABNT, 2008a) and ISO 14088 (ISO, 2009), with adaptations. About $250 \mathrm{ml}$ of crude analytical solution, after filtering through fabric and porosity crucible 2 , was subjected to filtering using medium filtration (white band) filter paper. After stirring, the filtrate was pipetted into a first $50 \mathrm{ml}$ aliquot, which was placed in the oven $\left(100^{\circ} \mathrm{C}\right)$ to obtain the dry mass of the residue by calculating soluble solids (SS) by Equation 4.

$S S=\%($ Mars $/$ Mae $) .100$

In which:

$\%$ SS = soluble solids;

Mars = dry mass ( $g$ ) of the filtrate residue extrapolated to the total volume of the solution (1L);

$\mathrm{Mae}=$ dry mass $(\mathrm{g})$ of the sample used in the extraction (Equation 2).

\subsection{Determination of tannin content}

Quantification of tannins by the skin powder method was based on the methodology presented by the technical standards D 6401-99 (ASTM, 2004a), NBR 11131 (ABNT, 2008b) and ISO 14088 (ISO, 2009). However, commercial skin powder was not used due to the difficulty of obtaining it and its high cost.

A portion of skin from cattle, was obtained in the city of Santa Cruz do Sul, RS. The skin was shaved using a salted knife and subsequently stretched and dried in the sun to produce the leather. This material did not undergo a tanning process using tannins therefore, which would likely impair its subsequent absorption of tannins in the laboratory. Using scissors, the leather was cut into smaller fragments, which were subjected to initial fragmentation in a forage machine, and subsequently in a Wiley Mill in order to reduce 
its particle size and thereby increase its surface area for absorption. Finally, the skin powder was stored in identified and tightly sealed containers, protected from light and humidity.

Before using the skin powder, it went through a chrome plating process, as required by the standard D 6401 (ASTM, 2004a). To $10 \mathrm{~g}$ of air-dried skin powder, 10 times the amount of distilled water was added, stirring the mixture for 30 minutes. After this, $1 \mathrm{ml}$ of chromium solution (concentration 3\%) was added for each gram of skin powder, stirring the mixture every 15 minutes for 2 hours. Subsequently, the sample was left to settle overnight. The following morning, the mixture was poured into flannel, allowing the liquid to drain, squeezing out the excess water and breaking apart the agglomerated powder after each washing. The amount of distilled water used in the washing corresponded to 15 times the weight of the skin powder $(150 \mathrm{ml})$. The process was repeated four times.

A third rate of $150 \mathrm{ml}$ was pipetted into the analytical solution, filtered and subsequently deposited into a container containing $10 \mathrm{~g}$ of chrome skin powder. After initial stirring with a glass rod, the mixture was left to stand for $24 \mathrm{~h}$. After this, the solution was once again filtered using white belt type filter paper. With a pipette, the filtrate was measured (approximately $80 \mathrm{ml})$, was and then placed in an oven $\left(100^{\circ} \mathrm{C}\right)$ to obtain dry mass. Non-tannic soluble solids (SSnT) were then calculated using Equation 5.

$\operatorname{SSnT} \%=($ Marf $/$ Mae $) .100$

In which:

SSnT \% = non-tannic soluble solids, in \%;

Marf $=$ dry mass of the residue in the filtrate extrapolated to the total volume of the solution (1L), in g;

Mae $=$ dry mass of the sample used in the extraction (Equation 2), g.

Considering that the tannic portion of the analytical solution was retained in the skin powder, it was calculated using the same Equation 6.

$T T p p \%=S S T-S S n T$

In which:

TTpp $\%=$ tannin content, in \%;

SS \% = soluble solids (Equation 4), in \%;

SSnT \% = non-tannic soluble solids (Equation 6) in \%.

\subsection{Blank test achievements}

As required by ASTM (2004a) and ISO (2009), the test was performed only by filtering distilled water through the skin powder, determining the dry residue of the filtrate and the corrections to be made from previous analyses.

\subsection{Experimental design and data analysis}

The experiment included particle mixtures for all individuals of the same species and parts (bark or fruit). It had a completely randomized design, with four treatments being evaluated: angico vermelho bark, jurema preta bark, acacia negra bark and angico vermelho fruit.

Three replicates were evaluated (extractions) per treatment and all sub-replicates (moisture content, total solids, total soluble solids, soluble solids tannic etc.) were analyzed in triplicate for each repetition.

The results were interpreted by comparison of means by Tukey test, considering $5 \%$ error probability.

\section{RESULTS AND DISCUSSION}

The analysis of variance of the moisture content showed no statistically significant difference between treatments $(p=0.0610)$, as was observed for the anhydrous mass of particles used in the extraction ( $\mathrm{p}=0.0613)$, as shown in Table 1.

For the average blank test, the mass of the residue of $0.355 \mathrm{~g}$ to $50 \mathrm{ml}$ aliquot was verified. Given that this value refers to the mass of material in the leaching process, this value was subtracted from the residue in the treatments.

Table 1. Mean comparisons of the moisture content and particle dry mass of particles used in the extraction.

\begin{tabular}{lcc}
\multicolumn{1}{c}{ Treatment } & $\begin{array}{c}\text { Moisture } \\
\text { content at } \\
\text { wet basis (\%) }\end{array}$ & $\begin{array}{c}\text { Dry mass of } \\
\text { particles (g) }\end{array}$ \\
\hline Angico-vermelho bark & $9.17 \mathrm{a}$ & $11.35 \mathrm{a}$ \\
\hline Acácia-negra bark & $8.60 \mathrm{a}$ & $11.43 \mathrm{a}$ \\
\hline Jurema-preta bark & $9.40 \mathrm{a}$ & $11.33 \mathrm{a}$ \\
\hline Angico-vermelho fruit & $8.43 \mathrm{a}$ & $11.45 \mathrm{a}$ \\
\hline Overall mean & 8.90 & 11.39 \\
\hline
\end{tabular}

Means followed by the same letter in the same column, do not show significant statistical differences by the Tukey test $(\mathrm{p} \geq 0.05)$ 
The moisture content on wet basis of the particles used in the extraction had an average of $8.90 \%$ and the anhydrous mass of particles presented an average of $11.39 \mathrm{~g}$. The highest values were 9.40 and $9.17 \%$ for the jurema and acacia negra barks, respectively. While $12.5 \mathrm{~g}$ of air dried particles were used for extraction, the quantities of anhydrous particles were $11.33 \mathrm{~g}$ (jurema), $11.43 \mathrm{~g}$ (jurema preta fruit), $11.35 \mathrm{~g}$ (angico vermelho) and $11.45 \mathrm{~g}$ (angico vermelho fruit). A tendency for the moisture content of jurema bark to exceed that of angico was observed. This was mainly due to the higher air humidity during the period in which they were dried. Additionally, the moisture present facilitated grinding the material, with little loss in the form of yarns and, consequently, with few incrustations in the mill knives.

Analyzing the moisture content of air dried bark of angico and jurema species, Paes et al. (2006a) observed lower results, with average values of $7.93 \%$ and $9.30 \%$, respectively, in a study conducted in the same region. These differences in humidity can be associated with the period when these authors conducted the study (dry season), the methodology and the storage location.

Analysis of variance of the total solids indicated a statistically significant difference between treatments $(\mathrm{p}<0.0001)$. Mean comparisons are presented in Table 2.

The total solids content can be understood as the total of the powdered extract. Comparing the species, the rofes negra bark stood out due to its higher values $(67.28 \%)$, followed by the angico vermelho bark (63.48\%), jurema bark (44. 60\%) and angico fruit $(43.68 \%)$, with the last two not statistically differing from one another.

Comparing the results obtained in this study with the literature was problematic given the different analytical techniques used by the other researchers and also because the methodology of the present study is relatively new and directed towards a potential species of the Caatinga biome. In a study of acacia species cultivated in Sudan,
Haroun et al. (2013) obtained an average of 51.8\% total solids for acácia negra. This difference may be related to the quantification method.

The variance analysis of soluble solids showed a statistically significant difference between treatments $(\mathrm{p}<0.0001)$. Mean comparisons are presented in Table 2.

The soluble solids correspond to a fraction of the total solids, and the other portion corresponds to the insoluble solid (difference between total solids and water soluble solids).

Angico vermelho bark stood out due to its higher soluble solids values (60.28\%), followed by acácia negra (49.83\%). Higher soluble solids values are preferable. However, one should also take into consideration other parameters such as the low non-tannic solids values in this extract.

Analysis of variance of insoluble solids indicated a statistically significant difference between treatments $(\mathrm{p}<0.0001)$. Mean comparisons are presented in Table 2.

Acácia negra bark stood out with its higher insoluble solids value in relation to the other species, and the others presented no significant differences to one another.

High insoluble values are undesirable. Therefore, despite acácia negra bark presenting high total solids values, a large part of this corresponds to insoluble solids. This was not observed with the other materials tested.

Analysis of variance of non-tannic soluble solids showed a statistically significant difference $(\mathrm{p}<0.0001)$. The mean comparison is shown in Table 2.

The highest value for non-tannic soluble solids was observed in angico bark (33.84\%). This amount is undesirable since a lower value for this parameter is preferable. The lowest non-tannic value was observed in jurema, with $20.83 \%$, indicating the potential use of this species as a source of tannins, with favorable chemical characteristics for skin tanning, since most components extracted were tannins.

Table 2. Mean comparisons of the total solids of extracts from different forest species.

\begin{tabular}{llcrcc}
\multicolumn{1}{c}{ Treatment } & ST (\%) & SS (\%) & IS (\%) & SSNT (\%) \\
\hline Angico-vermelho bark & $63.48 \mathrm{~b}$ & $60.28 \mathrm{a}$ & $5.75 \mathrm{~b}$ & $33.84 \mathrm{a}$ & $26.78 \mathrm{a}$ \\
Acácia-negra bark & $67.23 \mathrm{a}$ & $49.83 \mathrm{~b}$ & $17.42 \mathrm{a}$ & $21.42 \mathrm{c}$ & $28.40 \mathrm{~b}$ \\
Jurema-preta bark & $44.60 \mathrm{c}$ & $41.57 \mathrm{c}$ & $3.03 \mathrm{~b}$ & $20.83 \mathrm{c}$ & $20.74 \mathrm{c}$ \\
Angico-vermelho fruit & $43.68 \mathrm{c}$ & $37.09 \mathrm{~d}$ & $6.59 \mathrm{~b}$ & $28.05 \mathrm{~b}$ \\
\hline
\end{tabular}

Means followed by same letter in the same column, show no significant statistical differences by the Tukey test $(\mathrm{p} \geq 0.05)$. ST $=$ total solids; SS = soluble solids; IS = insoluble solid; SSNT = non-tannic soluble solids; TC = tannin content 
Analysis of variance of tannic soluble solids or tannins indicated a statistically significant difference $(F=226.13$, $\mathrm{p}<0.0001)$. The mean comparison is shown in Table 2 .

The tannin or tannic soluble solids correspond to a fraction of soluble solids, whereas the other fraction corresponded to non-tannic soluble solids. In this manner, soluble solids are divided into two portions, with the first corresponding to the non-tannic soluble solids and the second to the soluble tannic solids, the latter being the moiety which reacts with the skin powder.

For angico vermelho and acacia negra barks, the skin powder method is recomended due to the higher tannic values in comparison to jurema bark and angico fruit. However, it was found that acacia negra and angico vermelho barks did not statistically differ from one another, with angico vermelho bark presenting a higher value than acacia negra.

Acacia sp. species are in demand worldwide due to the high concentration of tannins in their tissues, ranging from 1 to $23 \%$ depending on the methodology used for quantification and the plant part used (Seigler et al., 1986).

Variations in tannin concentration are due to environmental factors, such as the quality of the site and the plant's genetics, since the concentration of tannin to the right of the shaft due to old trees, diameter, bark thickness, position in the trunk and spacing as described by Camillo (1997) who studied acacia negra plantations in southern Brazil.

Caldeira et al. (1998) studied two different acacia negra stands of Australian origin, which presented commercial value gains of $12.3 \%$ due to tannin concentration. At the same way, Rachwal et al. (2007), researching pure commercial acacia stands in the South of Brasil, obtained a tannin content of $14.5 \%$, a value lower than that found in the present study. Zheng et al. (1991), in turn, in a comparative study of the methods of foot skin and Stiasny, obtained better results than the present study for acacia negra bark, determined by skin powder method in the states of Tasmania, Victoria, South Australia and New South Wales, with 9, 46.6, 39.4 and $38.8 \%$, respectively.

In this sense, research into alternative raw materials to obtain tannins is important, since such studies in the Caatinga have demonstrated the richness in tannins in some species found in the region (Paes et al., 2006a; Paes et al., 2006b; Paes et al., 2010; Monteiro et al., 2005; Lima, 2011).
The variability in tannin chemical composition for each species and plant organ analyzed should be taken into account, which may influence its usefulness. With regard to jurema, in a study by Paes et al. (2006b), they demonstrated the technical viability of tannin extracted from this species for skin tanning, which may replace angico vermelho.

Comparing the results obtained by Camillo (1997), in which the author studied the total tannin concentration of acacia negra stands in Rio Grande do Sul, of different ages, the average total tannins at 3, 4, 5, 6, 7 and 8 years old was $14.83 ; 15.47 ; 14.35 ; 15.72 ; 14.11$ and $17.09 \%$, respectively. All the above results showed values lower than those obtained in this study.

According Panshin et al. (1962), tannins may represent from 2 to $40 \%$ of the dry weight of bark of various tree species. TANAC (2014) reported an approximately $28 \%$ tannin presence in acacia negra bark. Neither author, however, described the method used to obtain their results.

\section{CONCLUSIONS}

Angico vermelho presented potential similar to acacia negra, a global standard in the leather tanning industry. Jurema preta can also be used for this purpose, despite its lower tannin content (20.7\%) when compared to acácia negra and angico vermelho barks. The results for angico vermelho, in turn, did not show potential for this purpose.

\section{ACKNOWLEDGEMENTS}

Aos professores do Programa de Pós-graduação em Ciências Florestais da UFCG\CSTR, em especial ao meu orientador Professor Dr. Leandro Calegari.

\section{SUBMISSION STATUS}

Received: 3 july, 2017

Accepted: 26 july, 2017

\section{CORRESPONDENCE TO}

\section{Jordânia Xavier de Medeiros}

Departamento de Ciência Florestal - DCFL, Universidade Federal Rural de Pernambuco UFRPE, Rua Dom Manoel de Medeiros, $\mathrm{s} / \mathrm{n}$, 
Dois Irmãos, CEP 52171-900, Recife, PE, Brasil e-mail: jordaniamedeiros@hotmail.com

\section{FINANCIAL SUPPORT}

Coordenação de Aperfeiçoamento de Pessoal de Nível Superior (CAPES).

\section{REFERENCES}

American Society for Testing and Materials - ASTM. $D$ 6401-99: Standard test method for determining non-tannins and tannin in extracts of vegetable tanning materials. Pennsylvania: ASTM, 2004a. 4 p.

American Society for Testing and Materials - ASTM. D 6402-99: Standard test method for determining soluble solids and insolubles in extracts of vegetable tanning materials. Pennsylvania: ASTM, 2004b. 3 p.

American Society for Testing and Materials - ASTM. $D$ 6403-99: Standard test method for determining moisture in raw and spent materials. Pennsylvania: ASTM, 2004c. 3 p.

Associação Brasileira de Normas Técnicas - ABNT. NBR 11125: Insumos - Tanante - Determinação do teor de sólidos totais. Rio de Janeiro: ABNT. 2002. 2 p.

Associação Brasileira de Normas Técnicas - ABNT. NBR 14362: Insumos - Tanantes - Determinação do teor de sólidos solúveis e insolúveis - Método por gravidade. Rio de Janeiro: ABNT. 2008a. 3 p.

Associação Brasileira de Normas Técnicas - ABNT. NBR 11131: Insumos -Tanantes - Determinação do teor de constituintes não-tanantes e tanantes. Rio de Janeiro: ABNT. 2008b. 5 p.

Caldeira MVW, Schumacher MV, Santos ED, Viegas J, Pereira JC. Quantificação de tanino em três povoamentos de Acacia mearnsii De Wild. Boletim de Pesquisa Florestal 1998; 37: 81-88.

Camillo SBA. Influência dos fatores de sítio, espaçamento e idade na concentração e produção de tanino em povoamentos de Acacia mearnsii De Wild. [dissertação]. Santa Maria: Universidade Federal de Santa Maria; 1997.

Diniz CEF, Paes JB, Marinho IV, Lima CR. Avaliação do potencial tanífero de seis espécies florestais de ocorrência no semiárido brasileiro. In: Anais do Congresso Florestal Brasileiro [CD-ROM]; 2003; São Paulo. São Paulo: SBS/ SBEF; 2003.

Falcão L, Araújo MEM. Tannins characterization in historic leathers by complementary analytical techniques ATR-FTIR, UV-Vis and chemical tests. Journal of Cultural Heritage 2013; 6(14): 499-508. http://dx.doi.org/10.1016/j. culher.2012.11.003.
Haroun M, Khristova P, Covington T. Analysis of commercial vegetable tannin materials and related polyphenols of selected Acacia species in Sudan. Journal of Forest Products e Industries 2013; 2(1): 21-28.

Haslam E. Chemisty of vegetable tannins. London: Academic Press, $1966.170 \mathrm{p}$.

International Organization for Standardization - ISO. ISO 14088: Leather - Chemical tests - Quantitative analysis of tanning agents by filter method. Draft International Standard. Geneva: ISO; 2009.8 p.

Lima CR. Potencialidade dos extratos tânicos das espécies angico-vermelho, jurema-preta e jurema-vermelha no curtimento de peles caprinas [tese]. Campina Grande: Centro de Tecnologia e Recursos Naturais, Universidade Federal de Campina Grande; 2011.

Malacarne M, Antoniolli G, Bertoldi D, Nardin T, Larcher R. Botanical origin characterisation of tannins using infrared spectroscopy. Food Chemistry 2017; In press. http://dx.doi.org/10.1016/j.foodchem.2017.06.131.

Monteiro JM, Lins-Neto EMF, Amorim ELC, Strattmann RR, Araújo EL, Albuquerque UP. Araújo El, Albuquerque UP. Teor de taninos em três espécies medicinais arbóreas simpátricas da caatinga. Revista Árvore 2005; 29(6): 9991005. http://dx.doi.org/10.1590/S0100-67622005000600020.

Paes JB, Diniz CEF, Marinho IV, Lima RL. Avaliação do potencial tanífero de seis espécies florestais de ocorrência no Semiárido brasileiro. Cerne 2006a; 12(3): 232-238.

Paes JB, Marinho IV, Lima RA, Lima CR, Azevedo TKB. Viabilidade técnica dos taninos de quatro espécies florestais de ocorrência no Semi-Árido brasileiro no curtimento de peles. Ciência Florestal 2006b; 16(4): 453-462. http:// dx.doi.org/10.5902/198050981927.

Paes JB, Santana GM, Azevedo TKB, Morais RM, Calixto JT Jr. Substâncias tânicas presentes em várias partes da árvore angico-vermelho (Anadenanthera colubrina (Vell.) Brenan. var. cebil (Gris.) Alts.). Scientia Forestalis 2010; 38(87): 441-447.

Panshin AJ, Harrar ES, Baker WJ, Proctor PB. Forest products: their sources, production, and utilization. 2. ed. New York: McGraw-Hill; 1962.538 p.

Pizzi A. Tanin-based adhesives. In: Pizzi, A. (Ed.). Wood adhesives: chemistry and technology. New York: Marcell Dekker; 1993. p.177-246.

Rachwal MFG, Dedecek RA, Curcio GR, Simon AA. Manejo dos resíduos da colheita de acácia-negra (Acacia mearnsii De Wild.) e a sustentabilidade do sítio. Ciência Florestal 2007; 17(2): 137-144. http://dx.doi.org/10.5902/198050981945.

Ricci A, Parpinello GP, Olejar KJ, Kilmartin PA, Versari A. Attenuated Total Reflection Mid-Infrared (ATR-MIR) spectroscopy and chemometrics for the identification and classification of commercial tannins. Applied Spectroscopy 2015; 69(11): 1243-1250. http://dx.doi.org/10.1366/1507957. PMid:26647047. 
Seigler DS, Seilheimer S, Keesy J, Huang HF. Tannins from four common Acacia species of Texas and Northeastern Mexico. Journal of the Science of Food and Agriculture 1986; 29: 778-794.

TANAC. Taninos de Acácia [online]. Montenegro: TANAC S.A.; 2014. [cited 2015 Jan 18]. Available from: www.tanac.com.br

Wenzl HFJ. The chemical technology of wood. New York: The Academic Press; 1970. 692 p.
Yazaki Y, Gu R, Lin Y, Chen W, Nguyen NK. Analyses of black wattle (Acacia mearnsii) tannins - relationships among the hide-powder, the Stiasny and the ultra-violet (UV) methods. Holzforschung 1993; 47(1): 57-61. http:// dx.doi.org/10.1515/hfsg.1993.47.1.57.

Zheng GC, Lin YL, Yazaki Y. Tannin analysis of Acacia mearnsii bark - a comparasion of the hide-powder and Stiasny methods. Journal ACIAR Proceedings Series 1991; 35: 128-131. 